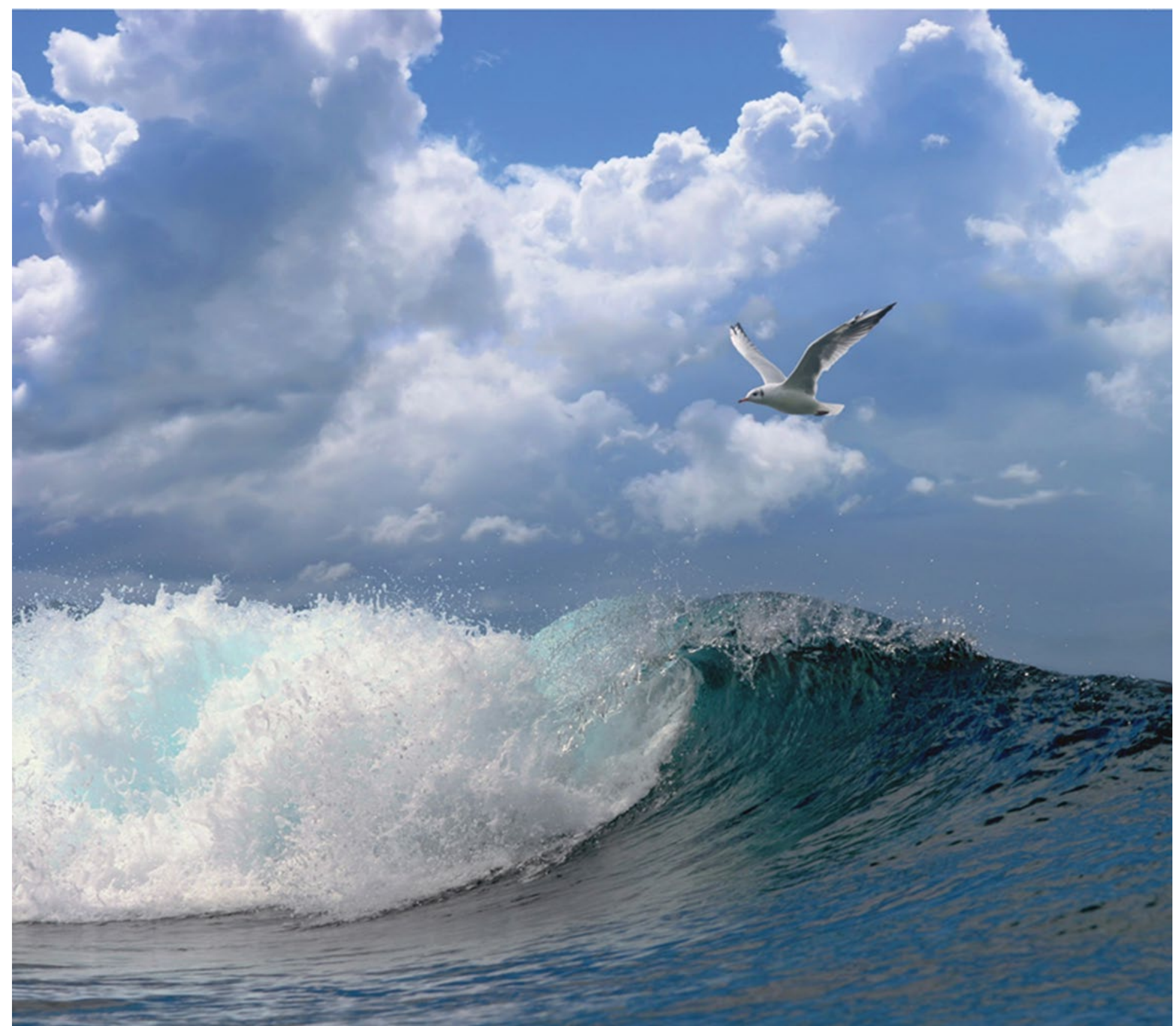

\title{
Natuurlijk Veilig: Meetplan kustsurvey 2020
}

Auteur(s): Joey Volwater, Ralf van Hal 


\section{Natuurlijk Veilig: Meetplan kustsurvey 2020}

Auteur(s): Joey Volwater, Ralf van Hal

Wageningen Marine Research 
Keywords: Suppletie, Kustzone, Platvis,

Opdrachtgever: RWS-WVL, hoogwaterveiligheid

T.a.v.: Petra Damsma

Postbus 17

8200 AA Lelystad

Dit rapport is gratis te downloaden van https://doi.org/10.18174/521379

Wageningen Marine Research verstrekt geen gedrukte exemplaren van rapporten.

Wageningen Marine Research is ISO 9001:2015 gecertificeerd.

\section{(C) Wageningen Marine Research}

Wageningen Marine Research, instituut binnen de rechtspersoon Stichting

Wageningen Research, hierbij vertegenwoordigd door Dr. M.C.Th. Scholten, Algemeen directeur

KvK nr. 09098104,

WMR BTW nr. NL 8113.83.696.B16.

Code BIC/SWIFT address: RABONL2U

IBAN code: NL 73 RABO 0373599285
Wageningen Marine Research aanvaardt geen aansprakelijkheid voor gevolgschade, noch voor schade welke voortvloeit uit toepassingen van de resultaten van werkzaamheden of andere gegevens verkregen van Wageningen Marine Research. Opdrachtgever vrijwaart Wageningen Marine Research van aanspraken van derden in verband met deze toepassing.

Alle rechten voorbehouden. Niets uit deze uitgave mag weergegeven en/of gepubliceerd worden, gefotokopieerd of op enige andere manier gebruikt worden zonder schriftelijke toestemming van de uitgever of auteur. 


\section{Inhoud}

$\begin{array}{lr}\text { Samenvatting } & 4\end{array}$

$1 \quad$ Inleiding $\quad 5$

1.1 Achtergrond $\quad 5$

1.2 Eerdere werkzaamheden 2016 - $2019 \quad 7$

1.3 Kustlangse en Westelijke Waddenzee survey in $2020 \quad 8$

$\begin{array}{ll}1.4 & \text { Randvoorwaarden }\end{array}$

2 Methoden $r$

2.1 Meetstrategie $\quad 10$

$\begin{array}{lll}2.1 .1 & \text { Doelsoorten vis } & 10\end{array}$

$\begin{array}{ll}2.1 .2 & \text { Temporele dekking } \\ 2.1 .3 & \text { Ruimtelijke dekking }\end{array}$

$\begin{array}{ll}2.1 .3 & \text { Ruimtelijke dekking } \\ & 10\end{array}$

2.1.4 Biotische en abiotische habitatvariabelen 11

$\begin{array}{ll}2.1 .5 & \text { Bemonsteringsinstrumenten }\end{array}$

2.2 Meetplan 12

2.2.1 Visbemonstering $\quad 12$

2.2.2 Vangstverwerking $\quad 12$

$\begin{array}{ll}2.2 .3 \text { CTD } & 13\end{array}$

$\begin{array}{lll}2.2 .4 & \text { Secchi } & 13\end{array}$

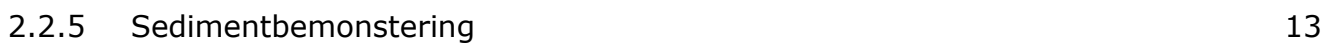

$\begin{array}{ll}2.2 .6 & \text { Personele inzet }\end{array}$

$\begin{array}{ll}\text { 2.2.7 Databeheer en -management } & 14\end{array}$

$3 \quad$ Kwaliteitsborging $\quad 15$

$\begin{array}{lr}\text { Literatuur } & 16\end{array}$

$\begin{array}{lr}\text { Verantwoording } & 17\end{array}$ 


\section{Samenvatting}

Suppleties van zand op vooroever of strand worden in opdracht van Rijkswaterstaat uitgevoerd om de Nederlandse kust tegen erosie te beschermen en om voldoende zand in het kustfundament te houden. Een groot deel van de suppleties vindt plaats in of nabij de kuststrook die binnen de Natura2000 regelgeving wordt beschermd, de Noordzeekustzone. Het is dus van belang de eventuele effecten van deze praktijk op de natuur zorgvuldig te bestuderen, zodat dit effect kan worden afgezet tegenover het algemene nut voor de maatschappij. Betere kennis van de effecten kan leiden tot beperking van eventuele schade aan- en mogelijk zelfs tot versterking van- gewenste natuurwaarden en ecosysteemdiensten. Tot nog toe is er in vergelijking met benthos relatief weinig aandacht geweest voor de gevolgen van suppleren op vispopulaties, terwijl de kinderkamerfunctie van de ondiepe kustzone voor vis een zeer belangrijke economische ecosysteemdienst levert. Kennis van de omgevingsfactoren die het voorkomen van juveniele vis in de ondiepe kustzone bepalen, leidt tot een verbeterd inzicht in de gevolgen van suppleties op vispopulaties en daarvan afhankelijk overig zeeleven.

In overleg met natuurorganisaties en de kennisinstituten Deltares en Wageningen Marine Research is in 2016 het document 'Ecologische effecten van zandsuppleties' (Herman et al., 2016) geschreven met als doel onderzoek te formuleren naar ecologische effecten van zandsuppleties. In het onderdeel 'uitvoeringsplan' (deel C in Herman et al. 2016) zijn 3 onderzoekslijnen (ook wel Krachtlijnen genoemd) gedefinieerd, te weten: Vooroever, Duinen en Waddenzee. Het hier beschreven meetplan voor een survey in 2020 valt onder de onderzoekslijn Vooroever. De onderzoeksvraag luidt: "Wat zijn de cumulatieve gevolgen van reguliere suppleties op samenstelling en functioneren van het ecosysteem van de ondiepe vooroever van de Nederlandse kust?" Deze volgt uit de prioritering van de krachtlijn Vooroever: (cumulatieve) gevolgen van reguliere suppleties op samenstelling en functioneren van het ecosysteem van de vooroever.

Het onderdeel dat in onze monitoring de hoogste prioriteit heeft gekregen is vis en dan met name de bodemgebonden (plat)vis omdat hier het meest directe effect van een verandering in sedimentsamenstelling door suppleties is te verwachten. Om de verspreiding en abundantie van deze vis in relatie tot omgevingsvariabelen zoals sedimentsamenstelling beter te begrijpen is er in 2017, 2018 en 2019 bemonsterd in de ondiepe vooroever (<10m) waarbij verschillende omgevingsvariabelen zijn bepaald. In 2017 en 2018 is dit gedaan voor specifieke gebieden met een experimentele opzet. Vanwege de beperkt beschikbare tijd (en de noodzaak van goede weersomstandigheden binnen dit tijdsbestek) leverde dit minder resultaten op dan vooraf verwacht. Vandaar dat in 2019 besloten is een andere opzet te kiezen waarbij de experimentele opzet minder van belang was. Er werd toen uitgebreider gekeken naar het ruimtelijke beeld langs de gehele Nederlandse kustzone. In navolging van 2019 wordt er voor 2020 opnieuw een kustlangse survey voorgesteld. Gedurende een week wordt er vanaf het onderzoeksschip de Luctor met een $3 \mathrm{~m}$ boomkor gevist en wordt er op dezelfde locaties een sedimentmonster genomen.

Voorlopige analyses van de eerder verzamelde gegevens laten zien dat de vangsten van schol in de kustzone vele malen lager zijn dan die in publicaties over de Waddenzee. Dit zou een werkelijk verschil in aanwezigheid van schol kunnen zijn, maar waarschijnlijk speelt de vangstefficiëntie van de gebruikte vistuigen hierin ook een rol. Om hier zicht op te krijgen, is er voor 2020 voorgesteld om in beide gebieden te bemonsteren met hetzelfde tuig. Om deze aanpassing op de kustlangse bemonstering zoals uitgevoerd in 2019 mogelijk te maken, is ervoor gekozen om het meest zuidelijke transect, langs de Zandmotor, uit de 2019 bemonstering te laten vervallen. Hiervoor in de plaats wordt een dag gebruikt om een transect op het Balgzand in de Waddenzee te bemonsteren. In 2020 gaat er vanuit IJmuiden tot aan Texel langs de kust op een diepte tussen 4-5 m bemonsterd worden, aangevuld met bemonsteringen op het Balgzand.

In 2019 zijn twee raaien naar dieper water $(12 \mathrm{~m})$ bemonsterd om inzicht te krijgen of de verspreiding van jonge schol zich enkel beperkt tot de 4-5m diepte zone, of dat ze in het voorjaar ook al aanwezig zijn in diepere wateren. Om meer inzicht op deze ruimtelijke verspreiding te krijgen zal er langs de kust in 2020 opnieuw geprobeerd worden een aantal raaien naar dieper water $(12 \mathrm{~m})$ te bemonsteren. 


\section{$1 \quad$ Inleiding}

\subsection{Achtergrond}

Suppleties van zand op vooroever of strand worden in opdracht van Rijkswaterstaat uitgevoerd om de Nederlandse kust tegen erosie te beschermen en om voldoende zand in het kustfundament te houden. Deze strategie wordt sinds enige decennia in Nederland toegepast en bestrijdt en voorkomt op effectieve wijze erosie van de zandige kust, zodat deze voldoende bescherming biedt en ruimte biedt aan diverse functies (Mulder e.a., 2011). Een groot deel van de suppleties vindt plaats in of nabij de kuststrook die binnen de Natura2000 regelgeving wordt beschermd, de Noordzeekustzone. Het is dus van belang de eventuele effecten van deze suppleties op de natuur zorgvuldig te bestuderen.

Rijkswaterstaat is opdrachtgever voor een meerjarig onderzoeksprogramma Ecologisch Gericht Suppleren II/Natuurlijk Veilig. In overleg met natuurorganisaties en de kennisinstituten Deltares en Wageningen Marine Research is in 2016 het document 'Ecologische effecten van zandsuppleties' (Herman e.a., 2016) geschreven met als doel onderzoek te formuleren naar ecologische effecten van zandsuppleties. In het onderdeel 'uitvoeringsplan' (deel C in Herman e.a. (2016)) zijn drie onderzoekslijnen (ook wel Krachtlijnen genoemd) gedefinieerd, te weten: Vooroever, Duinen en Waddenzee. In dit meetplan worden de gevolgen van reguliere suppleties op de samenstelling en het functioneren van het ecosysteem van de vooroever behandelt. De onderzoeksvraag luidt: "Wat zijn de cumulatieve gevolgen van reguliere suppleties op samenstelling en functioneren van het ecosysteem van de ondiepe vooroever van de Nederlandse kust?" Deze volgt uit de prioritering van de krachtlijn Vooroever: (cumulatieve) gevolgen van reguliere suppleties op samenstelling en functioneren van het ecosysteem van de vooroever.

De kinderkamerfunctie van de kustzone is van groot ecologisch belang voor vispopulaties en het daarvan afhankelijke overige zeeleven, en levert daarnaast een belangrijke economische ecosysteemdienst met betrekking tot de visserij (Brown e.a., 2018). Het belang van de vooroever specifiek is veel minder duidelijk, met name omdat er maar zeer sporadisch bemonsterd wordt. Uit bemonsteringen blijken er volwassen exemplaren voor te komen van soorten als tong (Solea solea), bot (Platichthys flesus) en sprot (Sprattus sprattus), voor welke de vooroever op het eerste oog geen vitale functie heeft omdat deze van een veel groter gebied gebruik maken. Daarnaast worden er net gesettelde jonge platvis met name schol (Pleuronectes platessa) maar ook in mindere mate tarbot (Scophthalmus maximus) en griet (Scophthalmus rhombus) gevangen. Deze kleine vis trekt naar mate ze groeien naar dieper water (van Keeken e.a., 2004; van Hal e.a., 2016). In de fase direct naar vestiging tot dat ze naar dieper water gaan is de vooroever voor de individuen die daar aankomen van vitaal belang. De vragen die we voor deze soorten zouden willen beantwoorden zijn:

- Is de vooroever als geheel even geschikt of zijn er locaties met een betere kinderkamerfunctie dan andere en zo ja, door welke omgevingsvariabelen wordt dit dan bepaald?

- Is de meerderheid van net gevestigde jonge platvis werkelijk beperkt tot de vooroever of hebben ze een grotere verspreiding in de kustzone?

- Draagt de vooroever significant bij aan de populatieomvang of is de bijdrage minimaal ten opzichte van andere kinderkamergebieden als de Waddenzee en de Voordelta met de Scheldes.

De Natuurlijk Veilig bemonsteringen in 2017, 2018 en 2019 hebben laten zien dat er in het gehele gebied van strand tot 10 m diep verschillende soorten jonge vis, o.a. schol, tong, wijting en haring voorkomt (van Hal e.a., 2017; van Hal en Dijkman Dulkes, 2018; Van der Geest, 2019; van Hal en Dijkman Dulkes, 2019). Hierbij werden de hoogste aantallen vis aangetroffen op een diepte van 5-6 $\mathrm{m}$, al is dit door het gebruik van verschillende bemonsteringsmethodes (4-10 m schip, 1-4 m rubberboot; <1 m lopend) lastig aan te tonen. Iedere bemonsteringsmethode heeft zijn eigen vangstefficiëntie en deze is helaas binnen de beschikbare mogelijkheden niet te bepalen. Doordat de 
vangstefficiëntie niet bekend is, is het ook niet mogelijk om absolute aantallen vis te kunnen uitrekenen.

Voorlopige analyses op basis van de gegevens (ongecorrigeerd voor vangstefficiëntie) uit de verschillende bemonsteringen geven de indruk dat de vangsten van juveniele platvis met name 0groep schol veel (10 tot 100 keer) lager zijn dan de aantallen die in de Waddenzee worden aangetroffen. Echter in de verschillende publicaties over de Waddenzee waarbij gevist is met een boomkor met een maaswijdte $10 \mathrm{~mm}$, is er altijd gecorrigeerd voor de vangstefficiëntie van dit specifieke tuig (van der Veer e.a., 2011; Freitas e.a., 2016). Vangstefficiëntie verschilt dus per vistuig en is afhankelijk van verschillende factoren o.a. type vistuig, maaswijdte van het net, breedte van het vistuig, vissoort en de grootte van individuele vissen (lengte) (Kuipers, 1975; Dapper, 1978; Aarts e.a., 2019). In de voorlopige analyses was het nog niet mogelijk om de vangstgegevens in de Waddenzee in absolute zin te kunnen vergelijken met die van de kustzone binnen Natuurlijk Veilig. De gecorrigeerde gemiddelde jaarlijkse piekvangsten over een aantal jaar in de periode 1975-2007 op

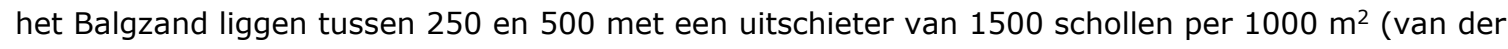
Veer e.a., 2011). Terwijl de ongecorrigeerde vangsten van het kornet met maaswijdte $20 \mathrm{~mm}$ in de zone $<1 \mathrm{~m}$ gemiddeld 10-15 met maxima tot 100 individuen per $1000 \mathrm{~m}^{2}$ waren.

In de recentere jaren is de grootste dichtheid van schol in de Westelijke Waddenzee verplaatst van de ondiepe zones zoals het Balgzand (intergetijdengebied) naar de diepere locaties o.a. de geulen (Freitas e.a., 2016). Hier werden in 2009 gemiddelde piekvangsten van boven de 500 schollen per $1000 \mathrm{~m}^{2}$, met een uitschieter van 1200 schollen per $1000 \mathrm{~m}^{2}$ aangetroffen. Dit gebied komt qua diepte meer overeen met het gebied dat de Luctor heeft bemonsterd met een boomkor met maaswijdte $10 \mathrm{~mm}$ voor Natuurlijk Veilig. De ongecorrigeerde resultaten hiervan in de diepte zone 4-7 $\mathrm{m}$ liggen ook duidelijk lager dan die (gecorrigeerd) in de Waddenzee (Figuur 1.1).

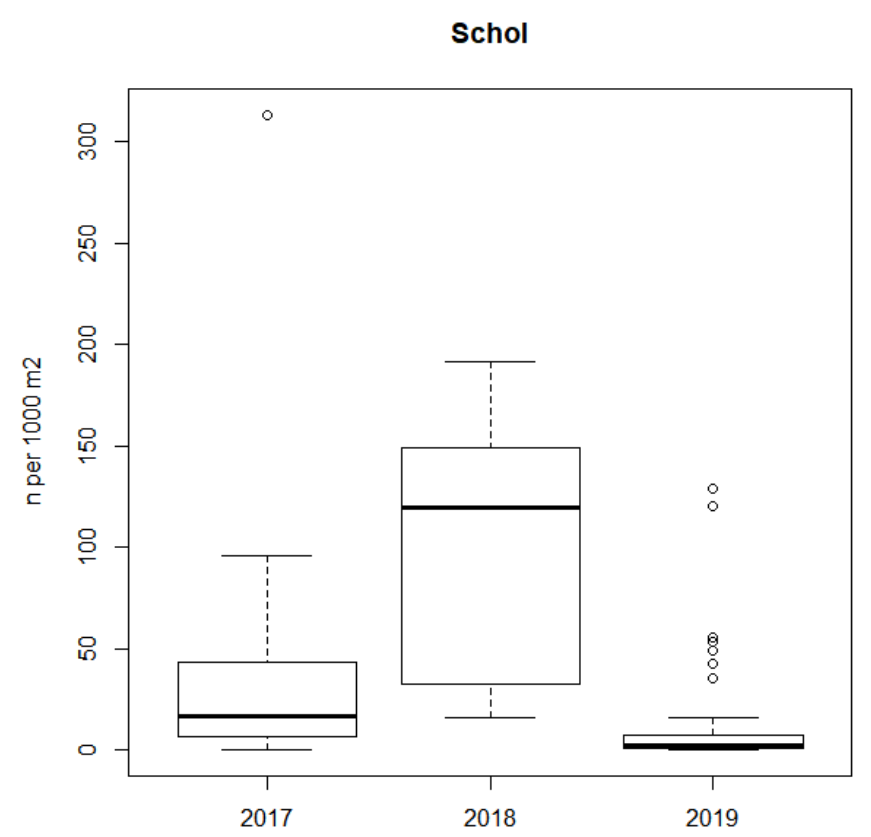

Figuur 1.1: Schol met lengte $<9 \mathrm{~cm}$; aantallen per $1000 \mathrm{~m}^{2}$ (zonder correctie voor net/tuig) uit de trekken uitgevoerd vanaf de Luctor met de boomkor in de diepte zone $<7 \mathrm{~m}$. Alleen monster uit juni/juli.

Een deel van dit verschil tussen de Natuurlijk Veilig vangsten en de resultaten uit de Waddenzee zit in het corrigeren voor de vangstefficiëntie. De grootte van het verschil roept echter vragen op over de vangstefficiëntie van de binnen Natuurlijk Veilig gebruikte tuigen, is de vangstefficiëntie van de gebruikte tuigen heel laag of vestigt er echt zoveel minder jonge schol in de kustzone? De vangstefficiëntie bepalen van de gebruikte tuigen is geen gemakkelijke opgave. Om toch enig beeld te krijgen van het verschil in aantallen tussen de Waddenzee en de kustzone, is het plan om met het in Natuurlijk Veilig gebruikte tuig in de Waddenzee te gaan vissen. De verwachting is dat er meer gevangen zal worden in de Waddenzee, maar dat het verschil minder groot zal zijn dan tussen de gepubliceerde getallen van de Waddenzee en de resultaten binnen Natuurlijk Veilig. De vangsten met het Natuurlijk Veilig tuig in de Waddenzee kunnen de getallen uit de kustzone in enig perspectief plaatsen. Als er in de Waddenzee ook daadwerkelijk veel meer schol gevangen wordt dan in de 
kustzone, dan liggen de verschillen met de publicaties over de Waddenzee niet aan de vangstefficiëntie maar aan de abundantie van schol. Als de vangsten in de Waddenzee vergelijkbaar zijn met die in de kustzone dan is waarschijnlijk een groot deel van het verschil met de publicaties over de Waddenzee toe te schrijven aan de vangstefficiëntie.

Als dichtheden van schol in de Waddenzee werkelijk vele malen groter zijn dan langs de Nederlandse Noordzeekustzone, dan is het belang van de kustzone voor de rekrutering en dus voor de Noordzee populatie op dit moment waarschijnlijk beperkt. Dit wordt versterkt als gekeken wordt naar het oppervlak van de vooroever, die is veel kleiner dan dat van de Waddenzee.

Voor de 2020 bemonstering wordt er voortgeborduurd op de opzet van de kustlangse survey van 2019 (van Hal, 2019). Hierin is op een diepte 4-6 m kustlangs vanaf de tweede Maasvlakte tot Texel om de 1,5-2 km een vistrek van 5 minuten uitgevoerd en een sedimentmonster genomen. Aanpassing hierop is dat in het huidige meetplan een voorstel wordt gedaan om zowel de vooroever als de Waddenzee te bemonsteren met hetzelfde vistuig. Door deze aanpassing moet het te bemonsteren gebied in de vooroever worden beperkt, van IJmuiden tot Texel, omdat opnieuw het onderzoeksschip maar één week beschikbaar is.

Dit rapport beschrijft de meetstrategie, de meetmethoden, de te meten variabelen (vis, macrobenthos (uit de boomkorvangsten) en omgevingsvariabelen) en de bemonsteringslocaties voor deze kustlangse bemonstering in 2020 .

\subsection{Eerdere werkzaamheden 2016 - 2019}

De ondiepe kustzone is nog niet vaak bestudeerd vanwege de slechte toegankelijkheid. Het is snel te ondiep voor schepen, maar te diep om te kunnen lopen. Schepen die hier wel kunnen bemonsteren zijn, doordat ze niet diep in het water liggen, gevoelig voor golven, die zich hier snel ontwikkelen. Om ervaring op te doen met gecombineerd toepassen van diverse bemonsteringstechnieken in ondiepe kustwateren is er een pilot bemonstering uitgevoerd in 2016. De belangrijkste bevindingen van de pilot survey (Couperus e.a., 2017) zijn samengevat in Baptist e.a. (2017) en beschrijven welke bemonsteringstechnieken ingezet zouden kunnen worden en hoeveel tijd deze in beslag nemen.

Op basis van de bevindingen in deze pilot is in 2017 de geïntegreerde ecosysteem survey ingericht waarbij vier vooraf geselecteerde kustvakken (Zuid-Holland, Noord-Holland, Texel en Ameland) langs de Nederlandse kust zijn bemonsterd. De selectie van deze vier gebieden was in eerste instantie gebaseerd op de verwachtte sedimentsamenstelling om hierin de maximale variatie te bemonsteren, en daarnaast op basis van de praktische mogelijkheden (Baptist e.a., 2017). Deze kustvakken zijn kenmerkend voor de Nederlandse kustregio's Hollandse kust en Waddenkust. In ieder van deze vier gebieden werden raaien met zeven monsterlocaties van strand tot 10 meter diepte gepland. In 2017 (12 juni t/m 7 juli) zijn alle vier de kustvakken bemonsterd (van Hal e.a., 2017), maar vanwege de weersomstandigheden zijn de gebieden Texel en Ameland niet volledig bemonsterd. Met name in het gebied Ameland zijn de ondiepste stations in zijn geheel niet bemonsterd.

In 2018 (18 t/m 22 juni) is één kustvak (Schiermonnikoog) bemonsterd (van Hal en Dijkman Dulkes, 2018), de geplande monsterposities overlapten deels met eerdere bemonsteringen uitgevoerd binnen EGS1 (Van Dalfsen e.a., 2014; Damsma e.a., 2017). Vanwege weersomstandigheden konden de ondiepste stations niet bemonsterd worden, deze zijn op 27 juni vanaf het strand alsnog bemonsterd.

In 2019 is er niet voor gekozen om een of meerdere kustvakken te bemonsteren maar is in de periode 17 tot 21 juni een kustlangse survey uitgevoerd. De survey was opgezet om de verspreiding en abundantie van (plat)vis in de vooroever te bepalen en deze te koppelen aan (a)biotische factoren. Vanaf de tweede Maasvlakte naar het noorden tot Texel zijn om de paar kilometer in totaal 69 locaties bemonsterd op een waterdiepte van 4-6 m. Naast deze kustlangse survey is er ook een strandbemonstering uitgevoerd. In de periode van 23 maart tot 23 juni is 1 à 2 keer per maand een strandbemonstering uitgevoerd in de meest ondiepe zone $(0-1 \mathrm{~m})$ van de Noordzee bij Texel, Castricum en Katwijk. Bemonsteringen zijn gedaan met voornamelijk een 1,8 m kornet met $20 \mathrm{~mm}$ maaswijdte (gestrekt) voortgetrokken vanaf het strand. 


\subsection{Kustlangse en Westelijke Waddenzee survey in 2020}

Een herhaling van een kustlangse bemonstering van de Noord-Hollandse kust in juni 2020 kan inzicht geven in de consistentie van het verkregen verspreidingspatroon in 2019. Natuurlijk kan (en zal) de verspreiding van jonge vis sterk van jaar op jaar variëren. Voortzetting van dit programma over meerdere jaren is dan eigenlijk ook nodig. Bij een voortzetting over meerdere jaren is het wellicht mogelijk om inzicht te krijgen in welke omgevingsvariabelen belangrijk zijn.

Uit de 2019 gegevens kwam naar voren dat een aantal lokale omgevingsvariabelen (doorzicht, sediment, wind) met elkaar correleerde (van Hal, 2019). Op de mooiste dagen met goed doorzicht werd er op net wat ander sediment gevist, dan op de dagen met wind en beperkter doorzicht. Het verschil in visvangst kon hierdoor niet toegewezen worden aan maar een van de omgevingsvariabelen. Een herhaling van de bemonstering, bij weer andere omstandigheden, zou hier aanvullend inzicht in kunnen geven. Al blijft dit natuurlijk een probleem als alle plekken maar een keer bemonsterd worden.

Een volledig vergelijkbare bemonstering als in 2019 is door de wens om ook de Waddenzee te bemonsteren niet mogelijk. Om die reden wordt er een dag in de Waddenzee gepland en vervalt er een dag waarin het zuidelijkste deel (kust van Zuid-Holland) langs de Zandmotor wordt bemonsterd. Voor de rest wordt de opzet van 2019 gevolgd waarbij met hetzelfde tuig gevist gaat worden in de diepte zone 4-6 m. Ondieper kan de Luctor niet bemonsteren en in dieper water is de verwachting dat het aantal 0-groep schol lager is. Dit laatste statement is gebaseerd op de raaien lopend van ondiep naar dieper water, welke in 2019 waren bemonsterd. In de diepere wateren is nauwelijks 0-groep schol gevangen, echter is er maar een gering aantal trekken verdeeld over 2 raaien bemonsterd, waarbij op de ondiepe locaties op deze raaien ook maar beperkte hoeveelheden 0-groep schol was gevangen. Om dit statement sterker te onderbouwen wordt voor 2020 voorgesteld om het aantal raaien uit te breiden naar ten minste vijf. Voor de locaties van de raaien zal gekeken worden naar de gegevens over de bodemschuifspanning.

Er wordt het volgende voorgesteld:

- Kustlangse survey (50-60 locaties) tot in de westelijke Waddenzee (Balgzand 10-15 locaties):

- Vanaf IJmuiden tot op het Balgzand op één diepte (4-5 m)

- Waarbij 5 raaien tot een diepte van $10 \mathrm{~m}$ worden bemonsterd

- Op vijf dieptes; 4, 6, 8, 10 en 12 meter

- Waarbij

- Gevist wordt met de $3 \mathrm{~m}$ boomkor (DFS-tuig) met maaswijdte $10 \mathrm{~mm}$ en registratie van:

- Aantallen vis en macrobenthos per soort

- Lengte van de vissen per soort

- Sediment genomen wordt met een happer

- Korrelgrootte van het sediment

- Waarbij CTD en doorzicht gemeten wordt

Naast dat de continuering van de Luctor bemonstering extra inzichten geeft is het ook voor latere onderzoeken relevant om gegevens te verzamelen in het voorjaar, de periode waarin in de meest recente jaren weinig tot geen gegevens beschikbaar zijn uit de kustzone.

Aanvullend op de voorgestelde werkzaamheden is het waardevol om otolieten te verzamelen van schol, tarbot en griet en hiermee de leeftijd te bepalen. Dit zou ook op basis van de lengte kunnen, echter lijkt een deel van de in 2019 gevangen schol te groot te zijn om tot de 0-groep te behoren, maar te klein voor de 1-groep. Otolieten zouden hier uitsluitsel over kunnen geven.

Aanvullend zouden deze otolieten gebruikt kunnen worden om de groeisnelheid op basis van de dagring incrementen te kunnen bepalen. Hoewel interessant voor Natuurlijk Veilig om het verschil in groeisnelheid tussen gebieden (met name Waddenzee ten opzichte van de Noordzeekustzone) te bepalen is de uitwerking hiervan geen onderdeel van het project. Maar hiervoor zal net als voor de eerdere extra werkzaamheden in eerdere jaren (RNA:DNA-analyses, maaginhouden op basis van DNA) geprobeerd worden een student(en) te vinden die dit op kan pakken. 


\subsection{Randvoorwaarden}

\section{Vergunningen}

Voor het verzamelen van materiaal van vissen (zoals weefselmonsters en otolieten) is een ontheffing nodig onder de Wet op Dierproeven omdat vissen gewervelde dieren zijn. Een projectplan is ingediend voor de 2017 survey met een langere looptijd. Hiervoor moet jaarlijks een vernieuwd proefplan ingediend worden, deze is opgesteld en ingediend op 7 april 2020. En op 16 april is de goedkeuring verkregen, onder het proefplannummer 2017.D-0005.004.

Voor bemonstering in de kustzone hebben we een ontheffing voor de NB-wet Noordzeekustzone DGAN-NB/ 1705626312 april 2017. Specificaties voor het 2020 onderzoek moeten 2 weken voorafgaande aan de bemonsteringen worden doorgegeven.

Voor de Waddenzee is het noodzakelijk een aanvullende aanvraag voor de NB-wet in te dienen. Hier wordt aan gewerkt. Op dit moment is er nog onduidelijkheid of LNV of de provincies voor dit onderdeel het bevoegde gezag zijn, hier wordt door het ministerie op dit moment naar gekeken.

\section{Weersgevoeligheid}

Voor de uitvoering van de bemonstering is goed weer (weinig wind en beperkte golfhoogte) nodig. Het risico bestaat dat de bemonstering op sommige dagen niet volledig uitgevoerd kan worden. Bij een golfhoogte boven de $1 \mathrm{~m}$ kan de Luctor eigenlijk geen werkzaamheden uitvoeren. Bij lagere golfhoogte zal er ter plekke beoordeeld moeten worden of uitvoering mogelijk is onder invloed van de lokale condities. 


\section{Methoden}

\section{$2.1 \quad$ Meetstrategie}

\subsubsection{Doelsoorten vis}

De doelsoorten zijn schol, tong, griet en tarbot. Deze platvissoorten liggen op of graven zich in het sediment en zijn daarmee afhankelijk van het type sediment. Dit sediment wordt mogelijk veranderd door de geplande zandsuppleties, wat dan een direct effect op deze soorten zou kunnen hebben. De focus van de bemonstering ligt op juveniele platvis en in het bijzonder op de 0 -jarige schol (opgroeiende vis in hun eerste levensjaar). 0 -jarige schol is de meest onderzochte platvis soort en leeftijdsgroep in de Noordzee, voornamelijk in de Waddenzee is veel onderzoek gedaan naar het voorkomen en de verspreiding van schol. De lengte van 0 -jarige platvis verschilt tussen soorten en verandert in de tijd. In juni 2020 is naar verwachting de lengterange van de juveniele platvissen 3-15 $\mathrm{cm}$. Daarom zal de bemonstering uitgevoerd worden met een $3 \mathrm{~m}$ boomkor waarbij een kleine maaswijdte $(1 \mathrm{~cm}$ gestrekt) in de kuil gehanteerd wordt.

Naast de doelsoorten zullen ook de overige gevangen vis en macrobenthos soorten, geregistreerd worden. Ook voor deze soorten kunnen we zodoende een beeld van de ruimtelijke verspreiding langs de Nederlandse kust geven.

\subsubsection{Temporele dekking}

De Luctor is beschikbaar in de week van 15 tot 19 juni 2020. Hiermee zijn vijf dagen beschikbaar voor de bemonstering, waarvan vrijdag waarschijnlijk alleen deels beschikbaar is voor bemonsteren, omdat de werkweek van de bemanning er op vrijdagmiddag op zit. De Luctor hoeft niet terug naar zijn thuishaven, Yerseke, op vrijdagmiddag. $\mathrm{Er}$ is in de week erna de mogelijkheid om terug te varen naar Yerseke. Er is naast de vijf beschikbare dagen geen mogelijkheid om de Luctor nog in te zetten, bij slecht weer in de periode 15 tot 19 juni vervalt het uit te voeren werk.

\subsubsection{Ruimtelijke dekking}

De gewenste ruimtelijke dekking is het bemonsteren van de Noord-Hollandse kustzone (4-5 m) en de westelijke Waddenzee (getijdengeulen en sub-getijden), van IJmuiden tot aan het Balgzand. Langs de Hollandse kust worden minstens vijf raaien naar dieper water tot twaalf meter bemonsterd $(4,6,8,10$ en 12). De thuishaven van de Luctor is Yerseke, maar er zou vertrokken kunnen worden vanuit IJmuiden afhankelijk van de weerberichten zou starten vanuit Den Oever (bereikbaar via binnenwateren) ook mogelijk zijn. Op de eerste dag ( $\mathrm{ma}$ ) zou het gebied vanaf IJmuiden tot iets voorbij Castricum (inclusief raaien) bestreken kunnen worden.

De tweede dag (di) kan er weer vanuit IJmuiden uitgevaren worden in de richting van Den Helder. De kustzone vanaf Castricum tot voor de kust van Petten kan bemonsterd worden, waarbij vervolgens de haven van Den Helder aan gedaan kan worden.

De derde dag (wo) zou het nog niet bemonsterde deel van de Noord-Hollandse kustzone tot Den Helder, inclusief raaien, bemonsterd kunnen worden. Aan het eind van de dag kan aangemeerd worden in Den Helder.

De vierde dag (do) kan gebruikt worden om de getijdengeulen en sub-getijden gebieden nabij het Balgzand, Westelijke Waddenzee, te bemonsteren. Laagwaterstand bij Den Oever wordt verwacht om $13 \mathrm{~h} 46(-71 \mathrm{~cm})$. 
De laatste dag (vr) kan dan gebruikt worden om in de omgeving rond Den Helder en voor de kust van Texel te bemonsteren, ook kan er een raai voor de kust van Texel bemonsterd worden. De gehele planning is erg afhankelijk van de weersomstandigheden, waarbij een dag met mindere condities ervoor kan zorgen dat een deel van de bemonstering niet kan worden uitgevoerd. In geval van slechte weerscondities eerder in de week, kan de laatste dag gebruikt worden om de eerder uitgevallen bemonsteringen alsnog uit te voeren. Prioritering hebben het Waddenzee traject en het traject van Den Helder naar het zuiden toe (IJmuiden).

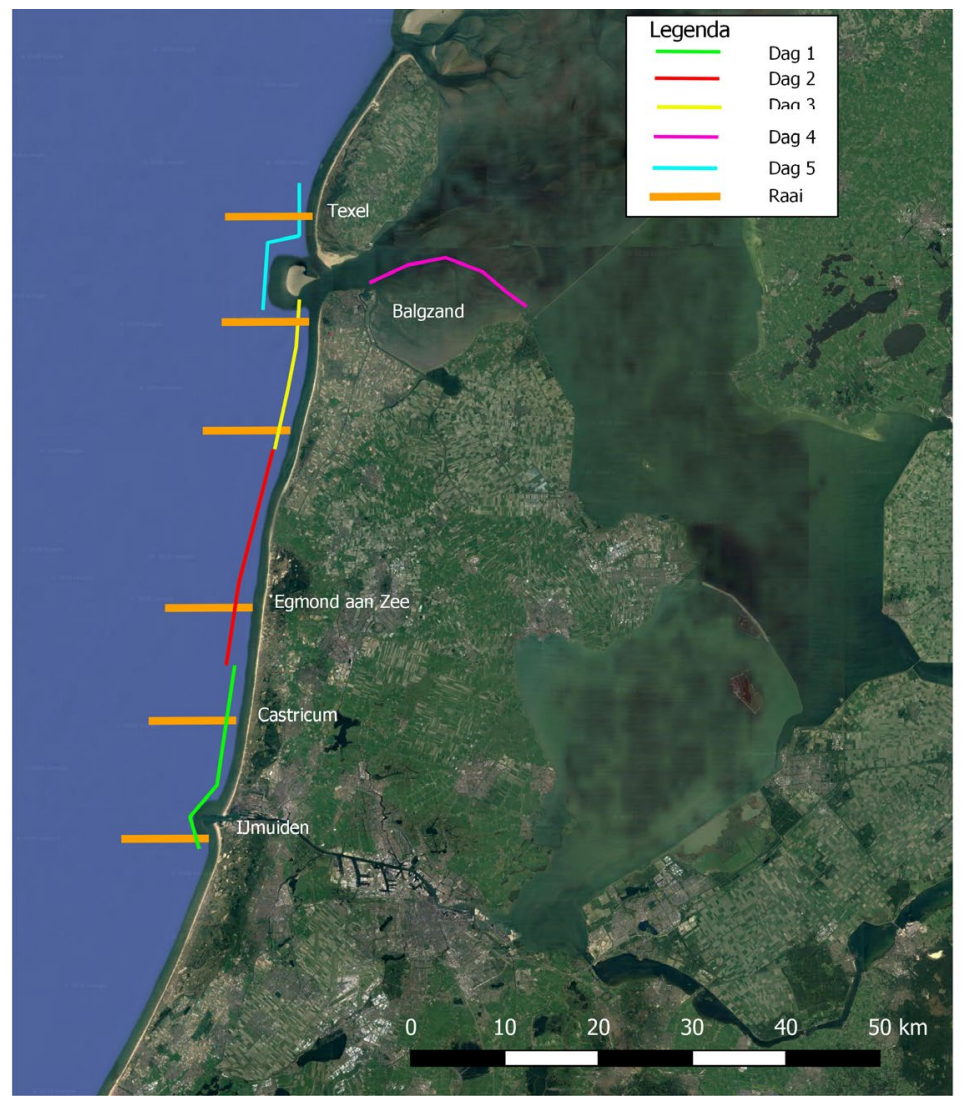

Figuur 3.1: Ruwe planning van de ruimtelijke verdeling per dag voor de beschikbare week voor het gewenste onderzoek.

De inschatting op basis van de bemonstering in 2019 is dat er per dag afhankelijk van de vaarafstanden ongeveer 15-20 locaties bemonsterd kunnen worden. In totaal komt dit uit op 75-100 bemonsteringslocaties verspreid langs de Noordzee kust en de Westelijke Waddenzee.

\subsubsection{Biotische en abiotische habitatvariabelen}

Om verschillen in de verspreiding van juveniele demersale vis eventueel te kunnen verklaren, worden er verschillende habitatvariabelen bepaald. Omdat de focus van dit onderzoek ligt op het verkrijgen van een ruimtelijk beeld van de verspreiding, worden alleen de habitatvariabelen bepaald die beperkte tijd kosten om uit te voeren.

De variabelen die gemeten gaan worden zijn:

- Sediment (korrelgroottesamenstelling)

- Waterdiepte (op startpunt en eindpunt van iedere vistrek)

- Zeewatertemperatuur

- Saliniteit

- Troebelheid/ Zichtdiepte 


\subsubsection{Bemonsteringsinstrumenten}

\section{Vis}

Demersale vis wordt bemonsterd met een $3 \mathrm{~m}$ boomkor (het DFS-tuig). Dit tuig heeft één wekker en een klossenpees. De maaswijdte in de kuil is normaliter $2 \mathrm{~cm}$ gestrekt, maar voor dit onderzoek wordt net als in 2019 een fijnmazige binnenkuil geplaatst van $1 \mathrm{~cm}$ gestrekt.

\section{Sediment}

Sediment wordt bemonsterd met een kleine van Veen happer. Uit de hap wordt met een steekbuisje van $26 \mathrm{~mm}$ diameter een core genomen voor de analyse van het sediment.

\section{Zoutgehalte, watertemperatuur, diepte en troebelheid/ doorzicht}

Er zal een CTD worden bevestigd op de $3 \mathrm{~m}$ boomkor. Deze CTD meet standaard conductiviteit (proxy voor saliniteit), watertemperatuur en druk (diepte). Daarnaast zal een extra sensor voor turbiditeit (troebelheid) toegevoegd worden aan de CTD.

Met een Secchi-schijf worden metingen van zichtdiepte gedaan vanaf de Luctor. Turbiditeit en zichtdiepte zijn niet recht evenredig met elkaar en de relatie tussen beide parameters verschilt afhankelijk van waterkwaliteitsparameters (zoals saliniteit). Derhalve geven de Secchi-schijf metingen extra informatie, ondanks dat dit een vrij grove meettechniek is.

\section{Otolieten}

Otolieten worden gebruikt om de leeftijd van vissen in jaren te bepalen. Voor dit doeleinde worden de otolieten van de gevangen platvissen verzameld om een onderscheid te kunnen maken in 0 en 1 groep.

\subsection{Meetplan}

\subsubsection{Visbemonstering}

De dagelijkse transecten zoals ingedeeld in Figuur 3.1, zijn voor de eerste 4 dagen hemelsbreed tussen de $20-30 \mathrm{~km}$. Het transect voor de laatste dag is korter. De inschatting is dat bij goede weersomstandigheden het bemonsteren van 15-20 locaties (dit is incl. raaien) haalbaar moet zijn. Bij slechtere omstandigheden zal dit niet haalbaar zijn, en kunnen vanwege het beperkt aantal beschikbare dagen niet ingehaald worden.

Rekening houdend met de te bemonsteren raaien betekent dit dat er om de $2-2,5 \mathrm{~km}$ gevist zou kunnen worden. In de praktijk zal dit vanwege nautische aspecten niet geheel uitvoerbaar zijn, maar er zal wel naar gestreefd worden. Wanneer de tijd het toelaat zal een deel van de Noordzeekustzone van Texel, inclusief een raai naar dieper water worden bemonsterd.

\subsubsection{Vangstverwerking}

De vangstverwerking gebeurt volgens de protocollen opgesteld in het handboek bestandsopnamen (van Damme e.a., 2019), met de volgende aanpassingen:

- Trekduur: 5 min

- Maaswijdte kuil: $1 \mathrm{~cm}$ gestrekt

- Alle vissoorten (soms groepen van soorten): lengtemetingen op de $\mathrm{mm}$ nauwkeurig

- Van de doelsoorten (schol, tong, tarbot, griet): lengte-gestratificeerd deelmonster samenstellen voor individuele gewichten $(0,1 \mathrm{~g}$ nauwkeurig).

- Van de doelsoorten (schol, tong, tarbot, griet): otolieten verzamelen met een maximum van 10 per soort per trek. Waarbij de focus ligt op individuen tussen de 0 - en 1-groep lengtes in.

- Zandspieringen (Ammodytes tobianus en A. marinus) worden aan boord gedetermineerd, ter controle wordt een random deelmonster meegenomen naar het lab.

Alle vissen en garnalen worden aan boord gedetermineerd tot op soortniveau (met enkele uitzonderingen zoals de grondels van het geslacht Pomatoschistus en de zandspiering van het geslacht Ammodytes die naar het lab gaan voor determinatie) en gemeten ( $\mathrm{mm}$ nauwkeurig). Dichtheden 
$(\mathrm{n} / \mathrm{ha}$ ) worden berekend uit de aantallen per trek, de afgelegde afstand binnen een trek en de breedte van het vistuig. Benthossoorten worden ook voor zover mogelijk uitgezocht tot op soortniveau en vervolgens geteld.

Deze gegevens worden aan boord in gevoerd in het WMR-invoersysteem Billie8, waarbij per vistrek een losse file wordt gecreëerd. $\mathrm{Na}$ afloop van de reis worden de files aangeboden aan een van de WMR-database beheerders en worden de files volgens een vastgelegde procedure gecontroleerd op fouten. Deze worden aan de reisleider voorgelegd ter aanpassing en bij goedkeuring worden gegevens in de WMR-database FRISBE geplaatst.

\subsubsection{CTD}

Er zal een vooraf gekalibreerde datalogger CTD voorzien van turbiditeitssensor bevestigd worden op de $3 \mathrm{~m}$ boomkor (Luctor), welke continue zal meten. De kalibratie wordt voorafgaande uitgevoerd door een WMR-technicus. De installatie en bediening wordt gedaan volgens de handleidingen van de betreffende apparaten.

Iedere ochtend zal een van de WMR-opstappers de CTD instellen zodat deze voor de nieuwe dag de metingen op slaat. Vervolgens wordt tijdens iedere vistrek met de boomkor de CTD (Conductiviteit, Temperatuur, Diepte) en turbiditeit (troebelheid) gegevens verzameld. Op het eind van de dag zal de WMR-opstapper de CTD weer uitlezen en worden de verzamelde gegevens van die dag opgeslagen op een van de laptops. Na afloop van de reis (of tijdens de reis als daar ruimte voor is) worden de CTDfiles gesplitst op basis van diepte, zodat er een file per vistrek wordt gecreëerd. Deze files worden op basis van het treknummer gekoppeld aan de visgegevens in de WMR-FRISBE-database.

\subsubsection{Secchi}

Vóór elke vistrek wordt een Secchi-schijf meting vanaf de Luctor uitgevoerd. De Secchi-schijf wordt te water gelaten aan de schaduwzijde van het schip tot een waterdiepte waarop de schijf niet meer zichtbaar is. Vervolgens wordt de schijf langzaam opgehaald, totdat deze weer zichtbaar is. Deze waterdiepte wordt genoteerd als Secchi-diepte op 0,25 m nauwkeurig. Bij golfslag wordt de schijf gehouden op een diepte waarop deze beurtelings wel en niet zichtbaar is en wordt de gemiddelde waterdiepte op 0,25 m nauwkeurig genoteerd. Indien de tijd het toelaat kan een $2 \mathrm{e}$ meting door een 2e persoon uitgevoerd worden. De Secchi-diepte is dan de gemiddelde van de twee waarnemingen. Deze wordt aan boord toegevoegd aan de Billie8-file van de betreffende trek.

\subsubsection{Sedimentbemonstering}

Op iedere locatie zal na het vissen met een kleine van Veen happer een sedimentmonster genomen worden. Met de happer wordt een representatieve hap genomen, waarvan tenminste de bovenste 10 $\mathrm{cm}$ intact is. Als dit niet goed gaat wordt het tot drie keer op nagenoeg dezelfde locatie geprobeerd, daarna wordt dit nog drie keer geprobeerd op een andere locatie op de beviste vislijn. Uit een goede hap wordt met een steekbuisje ( $26 \mathrm{~mm}$ diameter) sediment genomen, dit monster wordt ingevroren met vermelding van datum, locatie en sample-ID. De rest van de hap wordt over boord gezet, er wordt dus geen benthos bemonsterd.

De ingevroren sedimentmonsters worden extern (NIOZ Texel of AFS Wageningen, afhankelijk van beschikbaarheid) geanalyseerd op korrelgrootte met behulp van een Malvern mastersizer (2000 of 3000). De resultaten worden als Excel bestanden apart opgeslagen op de WMR-dataopslag server. Er wordt aan gewerkt om deze gegevens op trekniveau te kunnen koppelen en toe te voegen aan de FRISBE-database. Op dit moment is dat nog niet mogelijk.

\subsubsection{Personele inzet}

Voor zowel het veldwerk als het laboratoriumwerk zullen deskundigen ingezet worden. De personen die ingezet worden voor het veldwerk, inclusief hun gebied van expertise wordt gegeven in Tabel 1. 
Tabel 1 Personele bezetting veldwerk

\begin{tabular}{|l|l|l|}
\hline Week & Visbemonstering, CTD & Vis, benthos en sedimentbemonstering \\
\hline $15-19$ juni & Andre Dijkman-Dulkes & Yoeri van Es \\
\hline
\end{tabular}

\subsubsection{Databeheer en -management}

De resultaten van de visbemonsteringen worden aan boord in het WMR-invoersysteem Billie8 ingevoerd, wat de kans op typfouten verkleint. Na afloop van de survey worden op basis van de CTDgegeven hier ook gegevens over oppervlakte- en bodem-watertemperatuur en saliniteit aan toegevoegd s.

De in Billie8 ingevoerde gegevens worden gecheckt volgens standaardprocedure op allerlei mogelijke fouten (posities, lengte-gewicht relaties, max en minimale lengtes etc.) alvorens ze in de FRISBEdatabase van WMR geïmporteerd worden. Waarin ze permanent opgeslagen en beschikbaar blijven in het standaard format van de WMR vis- en benthosgegevens.

Vanuit de WMR-database worden de gegevens getransformeerd en omgezet in AQUO-standaard. In dit format worden de gegevens via de Wageningen Marine Research Geoserver als URL geleverd aan Informatie Huis Marien en Water Info Extra zodat op deze wijze de data via deze websites online beschikbaar worden gesteld als open data, waarbij de opslag plaats vindt bij WMR. 


\section{$3 \quad$ Kwaliteitsborging}

Wageningen Marine Research beschikt over een ISO 9001:2015 gecertificeerd kwaliteitsmanagementsysteem. Dit certificaat is geldig tot 15 december 2021. De organisatie is gecertificeerd sinds 27 februari 2001. De certificering is uitgevoerd door DNV GL. 


\section{Literatuur}

Aarts, G., S. Brasseur, J. J. Poos, J. Schop, R. Kirkwood, T. van Kooten, E. Mul, P. Reijnders, A. D. Rijnsdorp en I. Tulp (2019) Top-down pressure on a coastal ecosystem by harbor seals. Ecosphere 10: e02538.

Baptist, M., L. Bolle, B. Couperus, I. Tulp en R. v. Hal (2017) Ecologisch Gericht Suppleren: meetplan geïntegreerde ecosysteem survey 2017. Wageningen Marine Research.

Brown, E. J., R. P. Vasconcelos, H. Wennhage, U. Bergström, J. G. Støttrup, K. van de Wolfshaar, G. Millisenda, F. Colloca en O. Le Pape (2018) Conflicts in the coastal zone: human impacts on commercially important fish species utilizing coastal habitat. ICES Journal of Marine Science 75: 1203-1213.

Couperus, B., M. Baptist, D. Burggraaf, A. Dijkman-Dulkes, J. Perdon, M. Post en H. Verdaat (2017) Ecologisch gericht suppleren : verslag pilot multi-method survey 2016. Wageningen Marine Research.

Damsma, P., H. Holzhauer, T. Vermaas, B. van de Valk, L. van Duren en A. de Backer (2017) Ecologisch gericht suppleren I, resultaten van het onderzoek.

Dapper, R. (1978) De Balgzand scholgegevens 1975, 1976, 1977. NIOZ, 53 pagina's.

Freitas, V., J. I. J. Witte, I. Tulp en H. W. van der Veer (2016) Shifts in nursery habitat utilization by 0-group plaice in the western Dutch Wadden Sea. Journal of Sea Research 111: 65-75.

Herman, P., H. Meijer-Holzhauer, S. Vergouwen, J. Wijsman en M. J. Baptist (2016) Ecologische effecten van kustsuppleties; Systeembeschrijving (deel A), onderzoeksprioriteiten (deel B) en ontwerp uitvoeringsplan (deel C). Deltares, 100 pagina's.

Kuipers, B. (1975) On the efficiency of a two-metre beam trawl for juvenile plaice (Pleuronectes Platessa). Netherlands Journal of Sea Research 9: 69-85.

Mulder, J. P. M., S. Hommes en E. M. Horstman (2011) Implementation of coastal erosion management in the Netherlands. Ocean \& Coastal Management 54: 888-897.

Van Dalfsen, J. A., H. Holzhauer en E. Verduin (2014) Veldverslag bemonstering Ameland \& Schiermonnikoog $4 \& 5$ augustus 2014. Delft, Deltares.

van Damme, C., L. Bolle, I. de Boois, D. Burggraaf, B. Couperus, R. van Hal en T. Pasterkamp (2019) Handboek en protocollen voor bestandsopnamen en routinematige bemonsteringen op zee en in estuaria. CVO, CVO rapport 19.001

Van der Geest, M. (2019) Veldverslag strandsurvey Natuurlijk Veilig, maart - juni 2019. Wageningen Marine Research, 26 pagina's.

van der Veer, H. W., J. Koot, G. Aarts, R. Dekker, W. Diderich, V. Freitas en J. I. J. Witte (2011) Long-term trends in juvenile flatfish indicate a dramatic reduction in nursery function of the Balgzand intertidal, Dutch Wadden Sea. Marine Ecology Progress Series 434: 143-154.

van Hal, R., T. van Kooten en A. D. Rijnsdorp (2016) Temperature induced changes in size dependent distributions of two boreal and three Lusitanian flatfish species: A comparative study. Journal of Sea Research 107, Part 1: 14-22.

van Hal, R., B. Couperus, A. Dijkman-Dulkes en M. Baptist (2017) Reisverslag kustsurvey EGSII : Juni-juli 2017. Wageningen Marine Research.

van Hal, R. en A. Dijkman Dulkes (2018) Reisverslag kustsurvey EGSII : Juni 2018. Wageningen Marine Research.

van Hal, R. (2019) Ecologisch Gericht Suppleren: Meetplan kustlangse survey 2019. Wageningen Marine Research, C052/19.

van Hal, R. en A. Dijkman Dulkes (2019) Reisverslag kustsurvey Natuurlijk Veilig. Wageningen Marine Research.

van Keeken, O., M. van Hoppe, R. E. Grift en A. D. Rijnsdorp (2004) The effect of changes in the spatial distribution of juvenile plaice in the North Sea (Pleuronectes platessa) on the management of its stocks. ICES paper CM 2004/K:25. 


\section{Verantwoording}

Rapport C044/20

Projectnummer: 4312100053

Dit rapport is met grote zorgvuldigheid tot stand gekomen. De wetenschappelijke kwaliteit is intern getoetst door een collega-onderzoeker en het verantwoordelijk lid van het managementteam van Wageningen Marine Research

Akkoord:

Ingrid Tulp

Senior Onderzoeker

Handtekening:

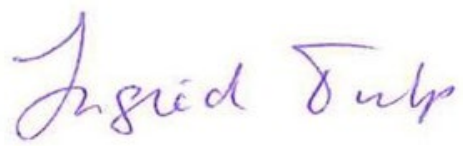

Datum:

6 mei 2020

Akkoord:

Drs. J. Asjes

MT lid Integratie

Handtekening:

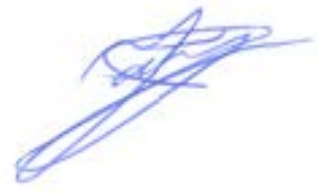

Datum:

6 mei 2020 
Wageningen Marine Research

T: $+31(0) 317480900$

E: marine-research@wur.nl

www.wur.nl/marine-research

Bezoekers adres:

- Ankerpark 271781 AG Den Helder

- Korringaweg 7, 4401 NT Yerseke

- Haringkade 1, 1976 CP IJmuiden
Wageningen Marine Research levert met kennis, onafhankelijk wetenschappelijk onderzoek en advies een wezenlijke bijdrage aan een duurzamer, zorgvuldiger beheer, gebruik en bescherming van de natuurlijke rijkdommen in zee-, kust- en zoetwatergebieden.
Wageningen Marine Research is onderdeel van Wageningen University \& Research. Wageningen University \& Research is het samenwerkingsverband tussen Wageningen University en Stichting Wageningen Research en heeft als missie: 'To explore the potential of nature to improve the quality of life' 